\title{
CHEMICAL AND NUTRITIONAL COMPOSITION OF COPAO FRUIT (Eulychnia acida PHIL.) UNDER THREE ENVIRONMENTAL CONDITIONS IN THE COQUIMBO REGION
}

\author{
Lilia Masson S. ${ }^{*}$, María Angélica Salvatierra G. ${ }^{2}$, Paz Robert C. ${ }^{1}$, Cristian Encina A. ${ }^{1}$, \\ and Conrado Camilo M. ${ }^{1}$
}

\begin{abstract}
Copao (Eulychnia acida Phil.) is an endemic arborescent cactus restricted mainly to the semi-arid Coquimbo Region ( $\left.29^{\circ} 54^{\prime} 28^{\prime \prime} \mathrm{S}, 71^{\circ} 15^{\prime} 15^{\prime} \mathrm{W}\right)$, Chile. The area of distribution is from sea level to $1200 \mathrm{~m}$.a.s.l. The edible fruit called rumpa is generally round, with green or pink peel and small scales on its surface, showing wide variability in size and weight. The aim of this work was to characterize the rumpa harvested in January 2009 and 2010 in three sectors of Coquimbo Region to determine chemical and nutritional composition in three fractions: pulp with seeds, juice, and peel. The research showed that this fruit is a good natural source of mainly soluble dietary fiber, which has a jellied texture and is present in the three fractions analyzed: $2 \%$ for juice, $3 \%$ for pulp with seeds, and approximately $5 \%$ for peel, making it potentially a

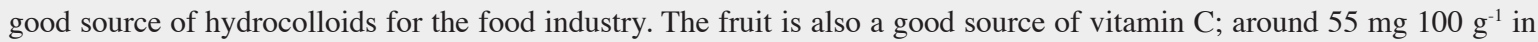
peel, and $30 \mathrm{mg} 100 \mathrm{~g}^{-1}$ in pulp with seeds and juice, values considered high compared to $18 \mathrm{mg} 100 \mathrm{~g}^{-1}$ for prickly pear (Opuntia ficus-indica [L.] Mill.) The main minerals were: $\mathrm{K}, \mathrm{Mg}, \mathrm{Ca}$, and $\mathrm{P}$. Total polyphenols and betalain pigments were also determined in the pulp with seeds and pink peel fractions, respectively. The nutritional characteristics, together with its high water content of around 96\%, make rumpa a promising raw material for agro-industrial development of natural juices or isotonic drinks. This characterization helps in the recovery of an endemic native species by reducing potential threats to destroy wild populations of E. acid, especially near agricultural areas, and by promoting habitat conservation of the species in the region.
\end{abstract}

Key words: Rumpa, arborescent cactus, vitamin C, minerals.

$\mathrm{T}$ he cactaceae family is xerophile and its cultivation has been commercially developed since the midtwentieth century. This family is native to Central Mexico, where the largest germplasm variability is found (Nefzaoui et al., 2008). Traditional Mexican medicine has historically used fruits or flowers of cactus cladodes to reduce serum cholesterol levels, regulate blood pressure, control gastric disturbances, and treat various diseases such as gastric ulcers, glaucoma, capillary fragility, rheumatic pains, etc. (Muñoz de Chávez et al., 1995; Domínguez-López, 1995; Gurrieri et al., 2000; Nefzaoui et al., 2008). Nopal fruits (Opuntia ficus-indica [L.] Mill.) are not only nutritious, but also a good source of functional components such as soluble dietary fiber, betalain and carotenoid pigments, minerals, and other compounds, such as highly appreciated antioxidants and

${ }^{1}$ Universidad de Chile, Facultad de Ciencias Químicas y Farmacéuticas, Centro de Investigación y Desarrollo en Grasas y Aceites, CIDGRA, Vicuña Mackenna 20, Santiago, Chile.

*Corresponding author (masson_lilia@yahoo.es).

${ }^{2}$ Instituto de Investigaciones Agropecuarias INIA, Apartado Postal 36-B, La Serena, Chile.

Received: 3 March 2011.

Accepted: 10 August 2011. gastro protective products. This is a real advantage for using this species as a source of bioactive compounds in the development of new functional foods (Sáenz, 2006; Nefzaoui et al., 2008).

Eulychnia is a genus present in Peru and Chile (Ritter, cited by Nyffeler et al., 1997), of which copao (Eulychnia acida Phil.) is an endemic species of arid regions, widely distributed in Coquimbo. It grows especially on hillsides facing north, from sea level up to 1200 m.a.s.1. (Bustamante, 1996). The fruit, called rumpa, is round or slightly elongated, with green or pink peel with very small scales. It presents a great variability in color, weight, and size. This morphological variability may be a response to environmental conditions (annual rainfall, altitude, temperature) and soil conditions, or it may have a genetic basis, as is the case with Stenocereus stellatus (Casas et al., 1999) and Stenocereus pruinosus (Luna, 2006). The raw pulp with seeds (fruit), with some sugar added, as well as its juice, is consumed locally, and the fruit is used as animal feed in the dry season. Once the fruit ripens, the peel becomes brightly colored, with a firm appearance, and the pulp tastes acidic and fruity. Although this species is widely distributed in the Coquimbo Region, practically no information on its chemical composition and nutritional 
value has been published. The information available to date on this species is related to its distribution and conservation status (Bustamante 1996), taxonomy, the morpho-anatomical characteristics of its stems (Nyffeler et al., 1997), and infestation by the leafless mistletoe Tristerix aphyllus. Therefore, the aim of this research was to characterize the chemical-nutritional composition of diverse fractions of the fruit to determine its potential use in agro-industry and thus help protect wild populations of this endemic native resource.

\section{MATERIALS AND METHODS}

\section{Samples}

Samples of ripe fruit from wild E. acida populations growing in the Coquimbo Region, Chile, were collected by hand during the fruit harvest period in January 2009 and 2010. Three sectors were chosen considering the differences of the wild population of cactus $E$. acida and climatic differences: 1) Manquehua sector (30 57' $\mathrm{S}, 71^{\circ} 10^{\prime} \mathrm{W}$; $660 \mathrm{~m}$.a.s.1.), an intermediate zone in Limari Valley with an annual mean temperature $16{ }^{\circ} \mathrm{C}$ and lower humidity than Gualliguaica; 2) Gualliguaica sector $\left(30^{\circ} 00^{\prime} \mathrm{S}, 70^{\circ} 48^{\prime} \mathrm{W}\right.$; 633 m.a.s.1.) located in Elqui Valley (Figure 1), with an annual mean temperature of $17{ }^{\circ} \mathrm{C}$ and an average relative humidity of around $60 \%$, and 3) the coastal Quebrada Honda sector (29³4' S, $71^{\circ} 10^{\prime} \mathrm{W}$; $\left.399 \mathrm{~m} . \mathrm{s} . \mathrm{s} .1.\right)$, this area is normally cloudy, with an annual mean temperature of $14{ }^{\circ} \mathrm{C}$ and an average relative humidity of around $80 \%$. Mean rainfall in the region during 2008 and 2009 was 125 and $61 \mathrm{~mm}$, respectively (CEAZA, 2010). Each sector was divided into three sub-sectors, approximately 6 ha each, with slope and northwest exposure, where the fruit samples

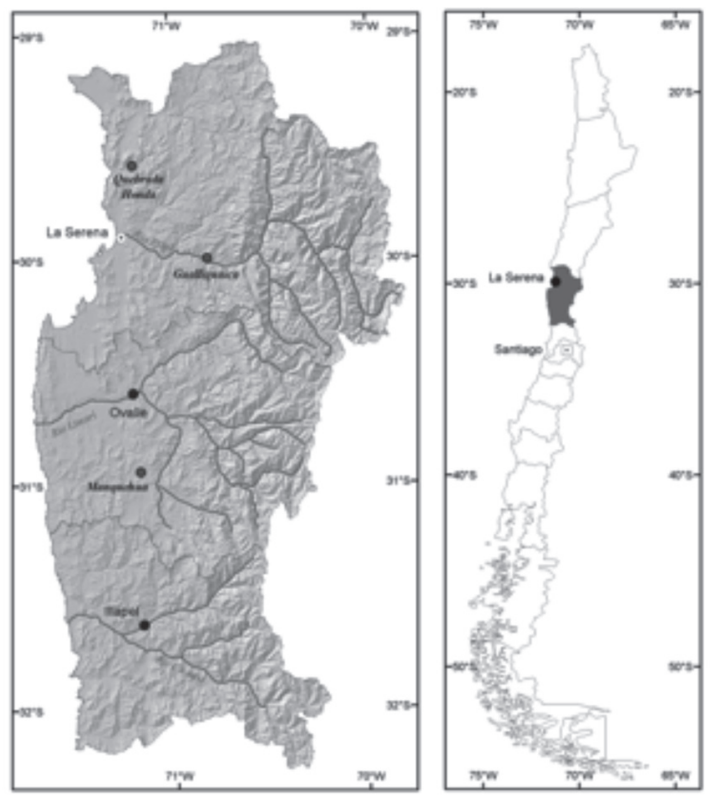

Figure 1. Region of Coquimbo: Three sectors sampled where fruits of Eulychnia acida were taken. were taken according to a previously designed sampling plan. On average, 70 plants full of fruits with good appearance were harvested at random per sub-sector, sampling between one to five ripe fruits per plant, located in the upper third of the stems. Due to the lack of information about the harvest index in this species, the fruits were harvested by direct appreciation according to experience of local inhabitants; then the parameters used were the brightness of the peel and the turgor of the fruits, detected visually, as indicators of the firmness and maturity of the fruits. As well, the fruits have different skin colors, so they were harvested in separate batches according to color, green or red, observed in the field (Figure 2).

Regarding peel color, green and pink peel fruits were collected separately only in Manquehua sector. In the other two sectors of Gualliguaica and Quebrada Honda, only green peel fruits were collected. Each lot taken in each sub-sector was around $15 \mathrm{~kg}$, with the following distribution: 1) Manquehua: three green and three pink peel fruit lots; 2) Gualliguaica: three green peel fruit lots; and 3) Quebrada Honda: three green peel fruit lots, with a total 12 lots. Each fruit was put in a special soft plastic bag commonly used in the country for exporting fruit, to protect them, labeled with its respective identification considering sector, subsector, peel color, date, lot number, and weight $(\mathrm{kg})$, and was delivered to the laboratory for analysis in a special refrigerated container.

In January 2010, a restricted fruit sampling procedure was conducted in the same three sectors sampled in 2009, applying the same criteria, the area of each sub-sector was smaller ( $2 \mathrm{ha}$ ), and the number of harvested plants was approximately 30 in total, sampling one to five fruits per plant. The sampling was smaller because of lower raw material requirements for chemical analysis. Each lot represented around $7 \mathrm{~kg}$ of fruits, taken randomly within the three subsectors previously defined per sector sampled, with the following distribution: Manquehua: one green and one pink peel fruit lot; Gualliguaica: one green and one pink peel fruit lot; and Quebrada Honda: one green peel fruit lot, for a total of five lots, three with green peel and two pink. The same procedure was used as in 2009 for packaging, labeling, and delivering the fruit lots to the laboratory.

Soil samples were taken from each sector and analyzed to determine organic matter content, $\mathrm{pH}$, and available $\mathrm{N}$ $\mathrm{P}$, and $\mathrm{K}$. The $\mathrm{pH}$ was neutral for the three sectors, ranging between 6.2 and 7.1. The content of $\mathrm{N}, \mathrm{P}$, and $\mathrm{K}$ in soil was higher in Quebrada Honda. The soil N content was 36, 19, and $23 \mathrm{mg} \mathrm{kg}^{-1}$ for Q. Honda, Gualliguaca, and Manquehua, respectively. While, the soil $\mathrm{P}$ content was 33, 20, and $24 \mathrm{mg} \mathrm{kg}^{-1}$ for Q. Honda, Gualliguaca, and Manquehua, respectively. Finally, the soil $\mathrm{K}$ content was 572, 316, and $139 \mathrm{mg} \mathrm{kg}^{-1}$ for Quebrada Honda, Gualliguaca, and Manquehua, respectively. 


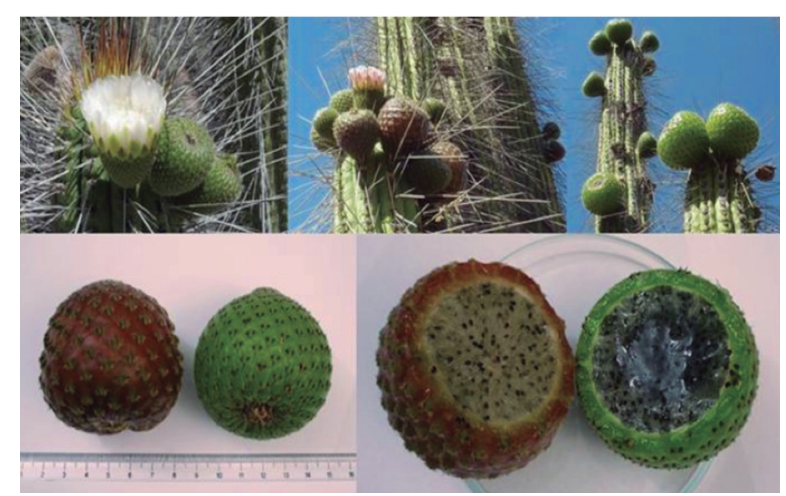

Figure 2. Rumpa fruits, pink and green peel; view of pulp with seeds.

\section{Analytical samples}

All fruit received in the laboratory was immediately weighed individually. Thus, more than 1700 individual fruits were assessed. Each lot was maintained at $-80 \pm$ $2{ }^{\circ} \mathrm{C}$ in a vertical freezer (Labtech Model LDF-8514, Namyangju, South Korea) until its analysis.

The analytical sample was approximatley $3 \mathrm{~kg}$ (average of 24 fruits). Each fruit was again weighed, halved longitudinally, the pulp with seeds was removed with a spoon. Because this is the edible fraction and thus more likely to be used in industry, it was collected in a weighted beaker for calculating the yield expressed as a percentage (weight ratios among the whole fruit, peel and pulp with seeds). The pulp and seed fractions obtained from 12 fruits from each sampling were homogenized in a commercial blender (Braun, Cincinnati, USA) until the seeds were completely ground. The homogenized samples were stored individually in labeled $250 \mathrm{~mL}$ plastic jars and submitted immediately to analytical determinations. Control samples of each analytical sample from fruit harvested in 2009 were kept at $-23 \pm 1$ ${ }^{\circ} \mathrm{C}$ (Freezer FENSA model FFH4450, Santiago, Chile). In the case of the 2010 sample, the same procedures described above for the analytical sample preparation were used for the five lots of sampled rumpa, with the difference that in this case two fractions from each analytical sample were obtained: five peel and five juice samples, for a total of 10 . Peel fractions were collected, weighed and homogenized in the same commercial blender. For the juice fraction, the seeds were separated from the pulp using an adequate sieve and the liquid was collected in labeled individual $250 \mathrm{~mL}$ plastic jars, and submitted immediately to analytical determination. A control sample of each analytical sample from fruit harvested in 2010 was kept at $-23 \pm 1{ }^{\circ} \mathrm{C}$. As a result of the 2009 and 2010 sampling procedures, three homogenized fruit fractions were analyzed: 12 analytical samples of pulp with seeds from rumpas harvested in 2009; and 10 analytical samples, five samples of peel and five of juice from rumpas harvested in 2010, 22 total samples. They were analyzed for proximate composition, including water, dietary fiber, available carbohydrates, lipids, nitrogen (protein), related to micronutrients, vitamin $\mathrm{C}$, $\mathrm{Ca}, \mathrm{Fe}, \mathrm{P}, \mathrm{K}, \mathrm{Mg}$, and $\mathrm{Cu}$.

Total polyphenols were only measured in the pulp with seeds fraction from fruits sampled from the three sectors during summer time 2009, and betalains pigments were determined in the pink peel fraction of fruit obtained from Manquehua sector sampled in 2009 and Gualliguaica and Manquehua sectors sampled in 2010. Each analytical determination was run at least in duplicate.

\section{Chemical analysis}

Moisture and volatile matter: The AOAC Official Method 934.01 (AOAC, 1995) was used with a forced-draft oven (MTB Binder, USA) at $103 \pm 2{ }^{\circ} \mathrm{C}$, with $5 \mathrm{~g}$ of sand added (Merck, Darmstadt, Germany). Total nitrogen was determined using the AOAC Official Method 954.01 (AOAC, 1995) through digestion and distillation (Büchi model 426, Flawil, Switzerland). Crude protein was calculated by multiplying total $\mathrm{N}$ by the universal factor 6.25. Total lipids were determined by the method of Bligh and Dyer (1959) with chloroform, methanol, and water in the inidicated proportions. The anthrone spectrophotometric method described by Osborne and Voogt (1986) was used to determine available carbohydrates. The glucose concentration in the sample test was calculated measuring its absorbance and results were expressed as a percentage (\%). Dietary fiber was determined by the AOAC Official Method 985.29 (AOAC, 1990) with the enzyme kit BIOQUANT® Total Dietary Fiber (Merck, Darmstadt, Germany). Ash was determined by the AOAC Official Method 930.05 (AOAC, 1995). Minerals were determined by the AOAC Official methods for each respective mineral as described in Volume 1 AOAC (1995). The method described by Schmidt-Hebbel (1977) was used to determine total ascorbic acid or vitamin $\mathrm{C}$. The vitamin $\mathrm{C}$ in the juice fraction was stabilized with an oxalic acid solution $0.5 \%$, and was measured in the spectrophotometer (Hitachi U-2900, Tokyo, Japan). The results were expressed as $\mathrm{mg}$ of total ascorbic acid or vitamin $\mathrm{C} 100 \mathrm{~g}^{-1}$ of fresh weight juice. The presence of polyphenols in the pulp with seeds fraction of fruits from 2009 was tested in an aqueous extract using the Folin Ciocalteau method (Singleton and Rossi, 1965). Total phenolic content was expressed as milligrams of gallic acid equivalents per $100 \mathrm{~g}$ of fresh pulp weight (mg GAE g ${ }^{-1} \mathrm{FW}$ ). Betacyanins and betaxanthin content was determined in a preliminary assay of the red peel fractions of fruits harvested in Manquehua in 2009, and repeated in the pink peel fraction harvested in Manquehua and Gualliguaica in 2010. They were determined in an aqueous peel extract using the spectrophotometric method proposed by Stintzing et al. (2005). Betacyanin and betaxanthin were expressed as $\mathrm{mg}$ of betanine and indicaxantin 100 $\mathrm{g}^{-1} \mathrm{FW}$ respectively. 


\section{Statistical analysis}

The data obtained were analyzed with an ANOVA. Means were compared with the Tukey test at a 95\% confidence level. The values of the weight of pulp and peel with respect to total fruit weight were determined by a nonparametric ANOVA (Kruskal-Wallis test). All statistical analyses were performed using the Statgraphic Plus 5.1 statistical software.

\section{RESULTS AND DISCUSSION}

\section{Physical characteristics}

The weight of the 1700 fruit sampled in January 2009 and 2010 ranged between $71 \mathrm{~g}$ up to $185 \mathrm{~g}$. The fruit weight showed significant interactions among sectors and between years (Table 1). The fruits harvested in Manquehua in 2009 and 2010 were the smallest, with an average weight of $100 \mathrm{~g}$, which was significantly different $(p<0.05)$ from the fruit from the other two sectors, $30 \%$ lower than fruit from Gualliguaica and 50\% less than fruit from Quebrada Honda. Fruit from both Gualliguaica and Quebrada were larger. However, there was significant variation in fruit weight between the two seasons in each sector, Manquehua being the sector with the smallest fruits in both years. The weight differences may be a consequence of physiological conditions of the plants, such as photoassimilate supply during fruit development (Inglese et al., 1999), climatic conditions such as rainfall (García Suárez et al., 2007) and soil moisture variations (Gugliuzza et al., 2002) in the three sectors during the two seasons. Considering pink and green peel color and the weight of fruits harvested in Manquehua in 2009 and Gualliguaica in 2010, Table 2 shows that Manquehua green peel fruits were smaller than pink peel fruits collected in the same sector, with a significant difference $(p<0.05)$. The weight difference was not significantly related to peel color in fruit from Gualliguaica, and therefore it is not easy to determine if peel color is related

Table 1. Fruit weight of rumpas (Eulychnia acida) sampled in three sectors of the Region of Coquimbo during summer 2009 and 2010.

\begin{tabular}{|c|c|c|}
\hline Sector & 2009 & 2010 \\
\hline & \multicolumn{2}{|c|}{ Fruit weight $(\mathrm{g})$} \\
\hline Gualliguaica & $147.88 \pm 37 \mathrm{Aa}$ & $133.33 \pm 29 \mathrm{Bb}$ \\
\hline Manquehua & $95.70 \pm 24 \mathrm{Bc}$ & $111.64 \pm 23 \mathrm{Ac}$ \\
\hline Quebrada Honda & $127.78 \pm 37 \mathrm{Bb}$ & $149.63 \pm 30 \mathrm{Aa}$ \\
\hline
\end{tabular}

Mean value \pm standard deviation. ANOVA $(\mathrm{P}<0.05)$ detected interaction between sector and year. Mean values followed by different uppercase letters on the same row, or followed by different lowercase letters in the same column denote significant differences according to Tukey's test $(\mathrm{P}<0.05)$.

Table 2. Fruit weight of rumpas (Eulychnia acida) according to their peel color, sampled in two sectors, during 2009 and 2010.

\begin{tabular}{lccc}
\hline Sector & $\mathrm{n}$ & Peel color & Fruit weight $(\mathrm{g})$ \\
\hline Manquehua & 392 & Green & $88 \pm 23 \mathrm{a}$ \\
& 458 & Pink & $104 \pm 23 \mathrm{~b}$ \\
Gualliguaica & 28 & Green & $133 \pm 25 \mathrm{c}$ \\
& 20 & Pink & $136 \pm 34 \mathrm{c}$ \\
\hline
\end{tabular}

Means value \pm standard deviation. Mean values with different letters denote significant differences $(\mathrm{P}<0.05)$. to weight. In any event, it is important to note that the number of fruits weighed in 2009 was much higher than in 2010. Regarding peel and pulp fruit color, in some cases the pink peel matched with the pulp, in other cases no relation was observed. The pulp of green-peeled fruits was always translucent white. All the green or pinkpeeled fruits had small scales on their sufaces, with very thin harmless thorns. Most of the fruits were round but some were slightly elongated (Figure 2).

Table 3 presents the yield percentage obtained for the pulp with seeds and peel fractions of E. acida according to sector and year sampled. In the three sectors, the peel fraction represented more than $50 \%$ of total weight. The highest yield of pulp with seeds was obtained in fruit from Manquehua, where the lowest fruit weight was also obtained (Table 1). In contrast, fruit from Quebrada Honda had the lowest pulp with seeds fraction yield and high average weight. Fruit from Gualliguaica had intermediate values. Yields were significantly different among the three sectors $(p<0.05)$. This means that the smallest fruits had a better pulp with seeds yield because their peels were thinner than the fruits grown in the other two sectors sampled in 2009 and 2010. Peel thickness increases with soil moisture (Mulas and D' hallewin, 1997), which may be caused by air humidity. As mentioned earlier, fruits from the three sectors showed morphological variations that are a phenotype expression influenced by environment, soil and genetic characteristics. It is necessary to do further research on these topics.

Each fraction of the fruit has its own physical characteristics; for example, the pulp with seeds has a jellied and filamentous texture, is yellow-brown, with small pieces of seeds in suspension, is acidic and has a fruity taste. The juice fraction is light yellow or pink, depending on the pulp color, the same jellied and filamentous texture and tastes acidy and fruity. Finally, the peel fraction has the same jellied texture, is green or pink, depending on the sampled sector, and tastes acidy.

\section{Nutritional composition}

The principal component was water with mean content at $92 \%$ for the pulp with seeds fraction, from fruits collected in 2009 in the three sectors. The water content was $93 \%$ and $96 \%$ for the peel and juice fractions respectively, obtained from green or pink-peeled fruits collected in 2010 in the same three sectors (Table 4). No clear influence was observed of peel color on water

Table 3. Proportion of fruit fractions in rumpa (Eulychnia acida) sampled in three sectors in the Region of Coquimbo.

\begin{tabular}{lrcc}
\hline Sector & $\mathrm{n}$ & $\begin{array}{l}\text { Pulp with seeds } \\
\text { (edible fraction) }\end{array}$ & Peel \\
\hline & & & \\
Manquehua & 223 & $49.2 \mathrm{a}$ & $50.7 \mathrm{c}$ \\
Gualliguaica & 184 & $47.1 \mathrm{~b}$ & $52.9 \mathrm{~b}$ \\
Quebrada Honda & 99 & $41.4 \mathrm{c}$ & $58.6 \mathrm{a}$ \\
\hline
\end{tabular}

Mean values obtained in 2009 and 2010. Mean values followed by different letters denote significant differences by Tukey's Test $(\mathrm{P}<0.05)$. Values were transformed to square roots. 
Table 4. Proximal analysis of different fractions in fresh weight of rumpa (Eulychnia acida) fruits in three sectors in the Region of Coquimbo.

\begin{tabular}{|c|c|c|c|c|c|c|c|c|c|}
\hline Fruit fraction & Sector & $\begin{array}{l}\text { Peel } \\
\text { color }\end{array}$ & Water & Total N & $\begin{array}{c}\text { Protein } \\
\left(\mathrm{N}^{*} 6.25\right)\end{array}$ & Lipids & $\begin{array}{c}\text { Carbo- } \\
\text { hydrates }\end{array}$ & Fiber & Ash \\
\hline & & & ${\mathrm{g} 100 \mathrm{~g}^{-1}}$ & $\mathrm{mg} 100 \mathrm{~g}^{-1}$ & & & g $100 \mathrm{~g}^{-1}$ & & \\
\hline \multirow[t]{4}{*}{ Pulp with seeds } & Manquehua & Green & $92.5 \pm 0.3 \mathrm{ab}$ & $191 \pm 9 \mathrm{a}$ & 1.0 & $1.2 \pm 0.1 \mathrm{a}$ & $0.56 \pm 0.03 \mathrm{a}$ & $3.1 \pm 0.1 \mathrm{a}$ & $0.62 \pm 0.05 b$ \\
\hline & & Pink & $92.2 \pm 0.5 \mathrm{a}$ & $187 \pm 5 a$ & 1.0 & $1.4 \pm 0.1 \mathrm{ab}$ & $0.57 \pm 0.06 \mathrm{a}$ & $3.2 \pm 0.1 \mathrm{a}$ & $0.68 \pm 0.07 b$ \\
\hline & Gualliguaica & Green & $93.1 \pm 0.4 \mathrm{~b}$ & $148 \pm 4 b$ & 0.8 & $1.3 \pm 0.1 \mathrm{ab}$ & $0.48 \pm 0.06 b$ & $2.9 \pm 0.4 \mathrm{a}$ & $0.59 \pm 0.03 \mathrm{a}$ \\
\hline & Q. Honda & Green & $90.9 \pm 0.7 \mathrm{c}$ & $197 \pm 10 a$ & 1.0 & $1.5 \pm 0.1 b$ & $0.59 \pm 0.03 \mathrm{a}$ & $3.5 \pm 0.3 \mathrm{a}$ & $0.86 \pm 0.04 \mathrm{c}$ \\
\hline \multirow[t]{5}{*}{ Peel } & Manquehua & Green & $93.3 \pm 0.1 b c$ & $56 \pm 1 \mathrm{a}$ & 0.35 & $0.13 \pm 0.01 b$ & $0.82 \pm 0.06 \mathrm{a}$ & $4.7 \pm 0.2 \mathrm{a}$ & $0.76 \pm 0.01 \mathrm{a}$ \\
\hline & & Pink & $93.4 \pm 0.1 \mathrm{c}$ & $48 \pm 0 \mathrm{a}$ & 0.30 & $0.09 \pm 0.01 \mathrm{a}$ & $0.80 \pm 0.06 \mathrm{a}$ & $4.5 \pm 0.1 \mathrm{a}$ & $0.94 \pm 0.01 b c$ \\
\hline & Gualliguaica & Green & $92.2 \pm 0.1 \mathrm{a}$ & $53 \pm 3 a$ & 0.33 & $0.14 \pm 0.01 \mathrm{~b}$ & $0.86 \pm 0.03 \mathrm{a}$ & $5.5 \pm 0.1 b$ & $0.92 \pm 0.04 b c$ \\
\hline & & Pink & $93.0 \pm 0.1 b$ & $49 \pm 3 a$ & 0.30 & $0.15 \pm 0.01 b$ & $0.87 \pm 0.06 \mathrm{a}$ & $4.8 \pm 0.2 \mathrm{a}$ & $0.86 \pm 0.01 \mathrm{~b}$ \\
\hline & Q. Honda & Green & $92.0 \pm 0.1 \mathrm{a}$ & $48 \pm 2 \mathrm{a}$ & 0.30 & $0.18 \pm 0.01 \mathrm{c}$ & $0.93 \pm 0.03 \mathrm{a}$ & $5.6 \pm 0.1 b$ & $1.00 \pm 0.03 c$ \\
\hline \multirow[t]{5}{*}{ Juice without seeds } & Manquehua & Green & $96.5 \pm 0.1 b$ & $38 \pm 1 c$ & 0.24 & $0.09 \pm 0.00 \mathrm{a}$ & $0.50 \pm 0.03 b$ & $2.1 \pm 0.1 \mathrm{a}$ & $0.52 \pm 0.01 \mathrm{ab}$ \\
\hline & & Pink & $96.5 \pm 0.1 b$ & $33 \pm 0 b$ & 0.21 & $0.11 \pm 0.00 \mathrm{c}$ & $0.43 \pm 0.01 \mathrm{~b}$ & $2.1 \pm 0.0 \mathrm{a}$ & $0.66 \pm 0.02 c$ \\
\hline & Gualliguaica & Green & $96.8 \pm 0.1 c$ & $28 \pm 1 \mathrm{a}$ & 0.17 & $0.10 \pm 0.00 \mathrm{~b}$ & $0.24 \pm 0.00 \mathrm{a}$ & $2.2 \pm 0.1 \mathrm{a}$ & $0.55 \pm 0.01 b$ \\
\hline & & Pink & $96.8 \pm 0.1 \mathrm{c}$ & $30 \pm 1 \mathrm{a}$ & 0.18 & $0.10 \pm 0.00 \mathrm{~b}$ & $0.25 \pm 0.00 \mathrm{a}$ & $2.2 \pm 0.1 \mathrm{a}$ & $0.48 \pm 0.01 \mathrm{a}$ \\
\hline & Q. Honda & Green & $96.3 \pm 0.1 \mathrm{a}$ & $28 \pm 0 \mathrm{a}$ & 0.18 & $0.15 \pm 0.00 \mathrm{~d}$ & $0.31 \pm 0.01 \mathrm{a}$ & $2.4 \pm 0.1 \mathrm{a}$ & $0.65 \pm 0.01 \mathrm{c}$ \\
\hline
\end{tabular}

Mean value \pm standard deviation; pulp with three replicates; peel and juice of two replicates; Mean values in the same fruit fraction followed by different letters within a column denote significant differences at $\mathrm{P}<0.05$

content of the fractions. The juice fraction presented significantly higher water content, $(96 \%)$ than the other two fractions, as expected $(\mathrm{p}<0.05)$. High water content plays an important function for fruit as physiological water reserves for the plant during the stressful hot and dry season after blooming. The values obtained for pulp with seeds were comparable to those found in other fruits, such as papaw (Vasconcellea pubescens (Lenne' et C. Koch) Badillo), sweet cucumber (Solanum muricatum Aiton) and watermelon (Citrullus lanatus (Thunb.), with 93.2, 92.4, and 93.5\%, respectively (Schmidt-Hebbel et al., 1992). On the other hand, the water values obtained were higher than those in the literature for nopal fruit from the genus Opuntia cacti, such as the prickly pear, with values between $83.8 \%$ and $91.0 \%$ (Askar and ElSamahy, 1981; Sawaya et al., 1983; Muñoz de Chavez et al., 1995; Pimienta, 1990; Sepúlveda and Sáenz, 1990; Schmidt-Hebbel et al., 1992; Rodríguez et al., 1996).

Regarding $\mathrm{N}$ in the three fractions, the values were low, from $30 \mathrm{mg} 100 \mathrm{~g}^{-1}$ for juice and as high as almost $200 \mathrm{mg} 100 \mathrm{~g}^{-1}$ for pulp with seeds, which is normal in fruits due to their high water content. The presence of the seeds, which represents a good $\mathrm{N}$ source, accounts for the higher content. These results are comparable to those with prickly pear fruit, with an $\mathrm{N}$ content between $34 \mathrm{mg} 100$ $\mathrm{g}^{-1}$ and $256 \mathrm{mg} 100 \mathrm{~g}^{-1}$ (Sawaya et al., 1983; Pimienta, 1990; Sepúlveda and Sáenz, 1990; Schmidt-Hebbel et al., 1992; Muñoz de Chavez et al., 1995; Gurrieri et al., 2000). We found no literature for $\mathrm{N}$ for rumpa fruit. The $\mathrm{N}$ content of rumpa fractions is also comparable to those of other typical fruits such as apple (Malus domestica

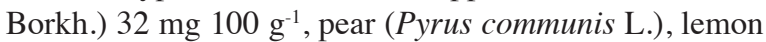
(Citrus limon (L.) Burm f.) $48 \mathrm{mg} 100 \mathrm{~g} \mathrm{~g}^{-1}$, apricot (Prunus

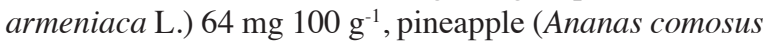
(L.) Merr., plums (Prunus domestica L.) $80 \mathrm{mg} 100 \mathrm{~g}^{-1}$, melon (Cucumis melo), grapes (Vitis vinifera L.) $96 \mathrm{mg}$ $100 \mathrm{~g}^{-1}$, orange (Citrus sinensis (L.) Osbeck) $112 \mathrm{mg}$ $100 \mathrm{~g}^{-1}$, peach (Prunus persica (L.) Batsch) $128 \mathrm{mg} 100$ $\mathrm{g}^{-1}$, and strawberry (Fragaria $\times$ ananassa Duchesne ex Rozier) 114 mg $100 \mathrm{~g}^{-1}$, (Cappelli and Vannucchi, 1990; Schmidt-Hebbel et al., 1992; Belitz and Grosch, 1999). The conversion to proteins presented values from $0.2 \%$ for the juice fraction up to $1 \%$ for pulp with seeds.

The lipid content is also low; the values obtained for the peel and juice fractions were close to $0.15 \%$, while the pulp with seeds presented a higher mean value of $1.4 \%$. The seeds represent a good source of this nutrient, as has been demonstrated in papaw ( $V$. pubescens), cherimoya (Annona cherimola), and prickly pear seeds obtained from these fruits cultivated in Chile, with mean lipid contents of 32.5, 18.5, and 5.5\%, respectively (Masson $e t$ al., 2008).

Regarding available carbohydrates, in the pulp with seeds and juice fractions the values were around $0.5 \%$ expressed in glucose. In the peel fraction, carbohydrates were comparatively higher than the percentage found in the other two fractions, at $0.8-0.9 \%$. The higher content could be explained by the peel texture, which is strong and thick, with a jellied texture that requires more structural materials.

Dietary fiber was the principal component in the three fractions, the peel presented a significantly higher value, of around $5 \%,(\mathrm{p}<0.05)$ than the other two fractions, at 2 to $3 \%$, which coincides with the higher content of carbohydrate found in the same fraction, confirming that the peel contains more components to maintain a strong external cover. The peel color did not have any influence on fiber content.

It is important to mention the special characteristics of the texture of the three fractions, as a result of the carbohydrate and dietary fiber values found. Dietary fiber in this fruit is mainly soluble fiber with a high proportion of thickening or gelling agents. These are considered water-soluble gums or hydrocolloids, composed of macromolecules that are easily dispersed in water, increasing viscosity and having a gelling effect 
(Multon, 2000). The high soluble dietary fiber content is a biological tool of the plant to capture and retain as much water as possible in dry areas. This content, from the technological point of view, is important because it could be a significant natural source of a thickening agent used as an additive in food industry (Multon, 2000).

The mineral content was around 0.5 to $1 \%$ in the three fractions and was slightly higher than the value reported for prickly pear fruit, with 0.40 and $0.51 \%$ (Askar and El-Samahy, 1981; Sawaya et al., 1983; Pimienta, 1990; Sepúlveda and Sáenz, 1990, Schmidt-Hebbel et al., 1992, Muñoz de Chávez et al., 1995; Rodríguez et al., 1996).

$\mathrm{K}, \mathrm{Mg}, \mathrm{P}$, and $\mathrm{Ca}$ were the principal minerals determined in the three fruit fractions (Table 5). $\mathrm{K}$ was the most homogeneous mineral with around $200 \mathrm{mg} 100 \mathrm{~g}^{-1}$ in the three fractions. $\mathrm{Mg}$ showed a significantly different distribution among the fractions $(\mathrm{p}<0.05)$ : in juice from 23 to $29 \mathrm{mg} 100 \mathrm{~g}^{-1}$, in pulp with seeds from $29-43 \mathrm{mg}$ $100 \mathrm{~g}^{-1}$ and the highest values in peel, with means between 41-44 mg $100 \mathrm{~g}^{-1}$. This distribution is probably related to physiological plant functions. Since green and pink peel fruits must have more chlorophyll pigments than the other fractions, $\mathrm{Mg}$ content would be higher in that fraction. $\mathrm{P}$ also showed variable fraction distribution, being clearly more concentrated in the juice fraction, with around 40 mg $100 \mathrm{~g}^{-1}$; pulp with seeds between 28-35 mg $100 \mathrm{~g}^{-1}$; and peel $5-8 \mathrm{mg} 100 \mathrm{~g}^{-1}$, the latter being very low. In contrast, Ca presented low values in juice, 6-7 mg $100 \mathrm{~g}^{-1}$; intermediate values in pulp with seeds, 12-16 mg $100 \mathrm{~g} \mathrm{~g}^{-1}$; and the highest values in peel, 50-60 mg $100 \mathrm{~g}^{-1}$, which could be because this mineral plays a role as structural material that is normally associated with pectin substances that contribute to maintaining structure and shape (Sáenz, 2006). Fe and $\mathrm{Cu}$ were very low; Fe presented a more homogeneous distribution between pulp with seeds and peel, around $20 \mathrm{mg} 100 \mathrm{~g}^{-1}$, with lower values in juice. $\mathrm{Cu}$ was very low in all three fractions $<0.1 \mathrm{mg} 100 \mathrm{~g}^{-1}$.
$\mathrm{Na}$ is one of the most abundant cations in nature and it showed great variation among the three fractions, with a tendency to be more concentrated in the peel. In relation to the sampling sectors, green-peeled fruit from the coastal zone of Quebrada Honda showed significantly higher values $(\mathrm{p}<0.05)$ in pulp with seeds for $\mathrm{K}, \mathrm{Mg}, \mathrm{P}$ and $\mathrm{Ca}$ compared to fruit from the other two sectors sampled in summer 2009. The same tendency was observed for the peel fraction obtained for fruits harvested in summer 2010 , with the exception of $\mathrm{Ca}$. These significantly higher values for minerals in pulp with seeds and peel in the coastal zone could be related to a different chemical soil composition or to other abiotic factors (Lester, 2006). Mineral soil conditions for $\mathrm{N}, \mathrm{P}$ and $\mathrm{K}$ varied among the evaluated sectors, but K content was higher at Quebrada Honda than at Gualliguaica and Manquehua. The presence of the components in the fruits is highly regulated by both genetic and environmental (soil and climate), factors (Lester and Crosby, 2002; Lester, 2006; Guzmán-Maldonado et al., 2010; Szakiel et al., 2010).

In addition, the seven minerals and water content were determined in samples of pulp with seeds of fruits harvested in 2010 in the same three sectors, in order to check if the data obtained in 2009 maintained the same order of magnitude. The mean values for each mineral did not show significant differences from those in determined in 2009, as shown in Table 5, with the exception of $\mathrm{P}$ content, which was lower than in 2009 for the same fraction (data not shown). Mg values were within the ranges in the literature for prickly pear pulp, with 16.1 to $98.5 \mathrm{mg} 100 \mathrm{~g}^{-1}$ (Sáenz, 2006). Mg is essential for humans due to its physiological role in adenosine triphosphate (ATP), and it has recently been suggested that moderate $\mathrm{Mg}$ deficiency could be a risk factor for chronic health problems, such as osteoporosis, cardiovascular disease and diabetes (Fleet and Cashman, 2003). Considering that $\mathrm{Mg}$ requirements for adult men and women are 320

Table 5. Element content of fruit fractions in fresh weight for rumpa (Eulychnia acida) from three sectors in the region of Coquimbo.

\begin{tabular}{|c|c|c|c|c|c|c|c|c|c|}
\hline Fruit fraction & Sector & $\begin{array}{l}\text { Peel } \\
\text { color }\end{array}$ & $\mathrm{Mg}$ & $\mathrm{Ca}$ & $\mathrm{P}$ & $\mathrm{F}$ & $\mathrm{Cu}$ & $\mathrm{K}$ & $\mathrm{Na}$ \\
\hline & & & & & & $-\mathrm{mg}_{100 \mathrm{~g}^{-1}}$ & & & \\
\hline \multirow[t]{4}{*}{ Pulp with seeds } & Manquehua & Green & $34.3 \pm 2.8 \mathrm{a}$ & $12.2 \pm 1.1 \mathrm{a}$ & $27.0 \pm 3.2 \mathrm{a}$ & $0.13 \pm 0.05 \mathrm{a}$ & $<0.1$ & $222 \pm 19 a$ & $12.4 \pm 7.2 \mathrm{a}$ \\
\hline & & Pink & $39.7 \pm 3.4 \mathrm{c}$ & $12.2 \pm 0.4 \mathrm{a}$ & $29.8 \pm 2.5 \mathrm{ab}$ & $0.15 \pm 0.02 \mathrm{ab}$ & $<0.1$ & $233 \pm 14 a$ & $18.1 \pm 10.4 \mathrm{a}$ \\
\hline & Gualliguaica & Green & $29.5 \pm 1.1 b$ & $12.9 \pm 0.2 \mathrm{a}$ & $25.2 \pm 3.4 \mathrm{a}$ & $0.22 \pm 0.04 \mathrm{bc}$ & $<0.1$ & $185 \pm 6 b$ & $11.2 \pm 7.3 \mathrm{a}$ \\
\hline & Quebrada Honda & Green & $43.3 \pm 2.8 \mathrm{c}$ & $16.4 \pm 2.1 b$ & $35.0 \pm 3.6 b$ & $0.20 \pm 0.01 \mathrm{c}$ & $<0.1$ & $286 \pm 17 c$ & $9.0 \pm 2.3 \mathrm{a}$ \\
\hline \multirow[t]{5}{*}{ Peel } & Manquehua & Green & $41.9 \pm 2.0 \mathrm{ab}$ & $51.2 \pm 1.9 \mathrm{a}$ & $5.3 \pm 0.4 \mathrm{ab}$ & $0.20 \pm 0.00 \mathrm{a}$ & $0.05 \pm 0.01 \mathrm{~b}$ & $163 \pm 8 \mathrm{a}$ & $48.5 \pm 1.6 \mathrm{~d}$ \\
\hline & & Pink & $45.6 \pm 0.1 b$ & $56.0 \pm 1.6 \mathrm{ab}$ & $5.7 \pm 0.2 b$ & $0.19 \pm 0.01 \mathrm{a}$ & $0.05 \pm 0.00 \mathrm{a}$ & $206 \pm 1 b$ & $48.3 \pm 1.1 d$ \\
\hline & Gualliguaica & Green & $41.3 \pm 0.2 \mathrm{a}$ & $63.9 \pm 0.2 \mathrm{c}$ & $8.2 \pm 0.1 \mathrm{c}$ & $0.19 \pm 0.01 \mathrm{a}$ & $0.05 \pm 0.01 \mathrm{a}$ & $207 \pm 3 b$ & $5.7 \pm 0.3 \mathrm{a}$ \\
\hline & & Pink & $41.6 \pm 0.8 \mathrm{a}$ & $56.2 \pm 1.2 b$ & $4.5 \pm 0.0 \mathrm{a}$ & $0.24 \pm 0.02 \mathrm{a}$ & $0.07 \pm 0.00 \mathrm{~b}$ & $221 \pm 9 b$ & $21.9 \pm 0.3 \mathrm{c}$ \\
\hline & Quebrada Honda & Green & $44.2 \pm 0.1 \mathrm{ab}$ & $64.7 \pm 0.3 c$ & $4.8 \pm 0.0 \mathrm{a}$ & $0.24 \pm 0.00 \mathrm{a}$ & $0.04 \pm 0.00 \mathrm{a}$ & $249 \pm 1 c$ & $15.0 \pm 0.3 b$ \\
\hline \multirow[t]{5}{*}{ Juice n } & Manquehua & Green & $29.3 \pm 0.1 \mathrm{c}$ & $7.1 \pm 0.0 \mathrm{c}$ & $35.2 \pm 0.6 a$ & $0.04 \pm 0.00 \mathrm{a}$ & $0.04 \pm 0.00 \mathrm{~b}$ & $139 \pm 1 \mathrm{a}$ & $33.6 \pm 0.0 \mathrm{e}$ \\
\hline & & Pink & $28.6 \pm 0.1 b$ & $6.8 \pm 0.2 b c$ & $42.6 \pm 0.9 b$ & $0.04 \pm 0.00 \mathrm{a}$ & $0.02 \pm 0.00 \mathrm{a}$ & $213 \pm 2 c$ & $6.9 \pm 0.4 c$ \\
\hline & Gualliguaica & Green & $24.1 \pm 0.0 \mathrm{a}$ & $6.6 \pm 0.1 b$ & $47.7 \pm 1.6 \mathrm{c}$ & $0.04 \pm 0.00 \mathrm{a}$ & $0.03 \pm 0.00 \mathrm{a}$ & $210 \pm 1 c$ & $2.1 \pm 0.0 \mathrm{a}$ \\
\hline & & Pink & $22.3 \pm 0.1 c$ & $5.4 \pm 0.0 \mathrm{a}$ & $45.7 \pm 0.6 b c$ & $0.03 \pm 0.00 \mathrm{a}$ & $0.02 \pm 0.00 \mathrm{a}$ & $180 \pm 8 b$ & $12.3 \pm 0.3 \mathrm{~d}$ \\
\hline & Quebrada Honda & Green & $28.8 \pm 0.1 \mathrm{a}$ & $6.7 \pm 0.1 b$ & $42.5 \pm 1.1 b$ & $0.03 \pm 0.00 \mathrm{a}$ & $0.02 \pm 0.00 \mathrm{a}$ & $174 \pm 1 b$ & $4.7 \pm 0.1 b$ \\
\hline
\end{tabular}

Mean value of three analytical samples \pm standard deviation.

Mean values in the same fruit fraction followed by different letters denote significant differences at $\mathrm{P}<0.05$. 
and $420 \mathrm{mg}_{\text {per }} \mathrm{d}^{-1}$, respectively, $100 \mathrm{~g}$ of pulp with seeds obtained from two rumpas fruit will contribute $10 \%$ of the $\mathrm{Mg}$ daily requirement (Fleet and Cashman, 2003). Regarding Ca content, Sáenz (2006) reported between

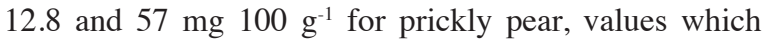
are in the range of the values found in this work for $E$. acida. The Daily Dose Reference (DDR) for adults, teens and children over 4 years of age old used in Chile is 800 $\mathrm{mg} \mathrm{d}^{-1}$, (Ministerio de Salud, 2005), and although rumpa contribution would be low, any contribution to the diet is important. In addition, a low intake of this mineral has long been related to osteoporosis, and several new relationships between dietary $\mathrm{Ca}$ and optimal human health (Weaver, 2003) have recently been established. For $\mathrm{P}$, the values for pulp with seeds and juice were in the range in the literature (Sáenz, 2006). Fe content was low compared to the literature (Sáenz, 2006), which reported $1.2 \mathrm{mg} 100 \mathrm{~g}^{-1}$ for prickly pear. Literature data for $\mathrm{Cu}$ was not found. $\mathrm{K}$ data were within the range of those reported in the literature for prickly pear, between 90 and $220 \mathrm{mg}$ $100 \mathrm{~g}^{-1}$ (Sáenz, 2006). $\mathrm{K}$ is the main intracellular cation and has a crucial role in various physiological processes. It enters all tissues and exerts deep effects on the function of some organs, in particular, the depolarization and contraction of the heart muscle (Preuss, 2003). Regarding $\mathrm{Na}$, prickly pear presents low values, 0.6-1.2 mg $100 \mathrm{~g}^{-1}$, compared to those in rumpa fractions (Sáenz, 2006).

Concerning bioactive components, rumpa can be considered a good source of vitamin $\mathrm{C}$, the peel fraction being the principal source with the highest mean values around 53-57 mg $100 \mathrm{~g}^{-1}$, followed by juice and pulp with seeds, with an average close to 35 and a range between $18-37 \mathrm{mg} 100 \mathrm{~g}^{-1}$, respectively (Table 6). It was observed that the peel color had some influence on the vitamin $\mathrm{C}$ content, because the green peel fraction presented higher vitamin $\mathrm{C}$ content than the pink peel. This difference was significant for the Manquehua sector $(p<0.5)$, where the green peel fraction showed the highest values of the three sectors sampled, with $61 \mathrm{mg} 100 \mathrm{~g}^{-1}$, followed by the

Table 6. Total vitamin $\mathrm{C}$ content of fruit fraction in fresh weight in rumpa for three sectors in the Region of Coquimbo.

\begin{tabular}{|c|c|c|c|c|}
\hline Fruit fraction & Season & Sector & Peel color & Total vitamin $\mathrm{C}$ \\
\hline \multirow{5}{*}{ Pulp with seeds } & \multirow{5}{*}{2009} & \multirow{3}{*}{ Manquehua } & & $\mathrm{mg} 100 \mathrm{~g}^{-1}$ \\
\hline & & & Green & $28.5 \pm 1.3 \mathrm{c}$ \\
\hline & & & Pink & $36.7 \pm 1.5 \mathrm{~d}$ \\
\hline & & Gualliguaica & Green & $25.7 \pm 3.4 b$ \\
\hline & & Quebrada Honda & Green & $17.7 \pm 1.6 \mathrm{a}$ \\
\hline \multirow[t]{5}{*}{ Peel } & \multirow[t]{5}{*}{2010} & \multirow[t]{2}{*}{ Manquehua } & Green & $61.0 \pm 0.6 \mathrm{a}$ \\
\hline & & & Pink & $54.1 \pm 0.7 b$ \\
\hline & & \multirow[t]{2}{*}{ Gualliguaica } & Green & $55.2 \pm 1.1 b$ \\
\hline & & & Pink & $50.5 \pm 1.4 b$ \\
\hline & & Q, Honda & Green & $52.7 \pm 1.9 b$ \\
\hline \multirow{5}{*}{$\begin{array}{l}\text { Juice without } \\
\text { seeds }\end{array}$} & \multirow[t]{5}{*}{2010} & \multirow[t]{2}{*}{ Manquehua } & Green & $37.8 \pm 1.4 \mathrm{c}$ \\
\hline & & & Pink & $32.7 \pm 0.3 b$ \\
\hline & & \multirow[t]{2}{*}{ Gualliguaica } & Green & $34.0 \pm 0.1 b$ \\
\hline & & & Pink & $34.2 \pm 3.9 b$ \\
\hline & & Quebrada Honda & Green & $21.7 \pm 2.6 a$ \\
\hline
\end{tabular}

Mean value of four replications \pm standard deviation; Mean values in the same fruit fraction followed by different letters denote significant differences at $\mathrm{P}<0.05$.
Gualliguaica sector with $55 \mathrm{mg} 100 \mathrm{~g}^{-1}$. The lowest value for the pink peel fraction was from the Gualliguaica sector,

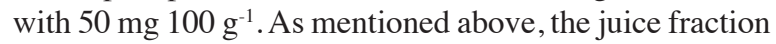
was also important for vitamin $\mathrm{C}$ contribution obtained from green peel fruits harvested in the Manquehua and Gualliguaica sectors, confirming that the Quebrada Honda coastal sector, presented the lowest values. The pulp with seeds also presented high total vitamin $\mathrm{C}$ content, mainly in pink peel fruits from Manquehua. Fruit from Quebrada Honda again presented the lowest values. The different contents of vitamin $\mathrm{C}$ could be related to the environmental conditions of the three sectors (Lester, 2006). This interesting contribution of vitamin $C$ from the three fruit fractions must be enhanced because they exceed largely those reported for several commonly consumed fruits such as plums ( $P$. domestica) $3 \mathrm{mg} 100$ $\mathrm{g}^{-1}$, watermelon (Citrullus lanatus) $3.6 \mathrm{mg} 100 \mathrm{~g}^{-1}$, pear (P. communis), banana (Musa paradisiaca) $4 \mathrm{mg} 100 \mathrm{~g}^{-1}$, apple (M.domestica) $6 \mathrm{mg} 100 \mathrm{~g}$, peach $(P$. persica) $7 \mathrm{mg}$ $100 \mathrm{~g}^{-1}$, apricot (P. armeniaca) $9 \mathrm{mg} 100 \mathrm{~g}^{-1}$, pineapple (A. comosus) $25 \mathrm{mg} 100 \mathrm{~g}^{-1}$, fresh papaw (V. pubescens) and pepino (Solanum muricatum Aiton) $26 \mathrm{mg} 100 \mathrm{~g}^{-1}$; and only less than fruits recognized as good source of vitamin $\mathrm{C}$ such as strawberries (Fragaria $\times$ ananassa) $60 \mathrm{mg} 100 \mathrm{~g}^{-1}$, lemon (C. medica) $61 \mathrm{mg} 100 \mathrm{~g}^{-1}$, orange (Citrus sinensis (L.) Osbeck) $83 \mathrm{mg} 100 \mathrm{~g}^{-1}$ and kiwi (Actinia chinensis Planch.) $96 \mathrm{mg} 100 \mathrm{~g}^{-1}$. Rumpa also presented higher values than prickly pear with $18 \mathrm{mg}$ $100 \mathrm{~g}^{-1}$ (Cappelli and Vannucchi, 1990, Schmidt-Hebbel et al., 1992, Belitz and Grosch, 1999). It is important to note that the $100 \mathrm{~g}$ vitamin $\mathrm{C}$ content of rumpa pulp with seeds or $100 \mathrm{~g}$ of juice (around two rumpa fruits) can contribute practically $50 \%$ of the vitamin C DDR or 60 $\mathrm{mg} \mathrm{d}^{-1}$ (Ministerio de Salud, 2005).

The lowest value of total polyphenol content, expressed as a gallic acid equivalent (GAE) per $100 \mathrm{~g}^{-1}$, was found in fruit from Manquehua. Fruit from Gualliguaica presented intermediate values and the highest were found in fruit from the coastal area of Quebrada Honda. The general range was between 44.3 and $78.1 \mathrm{mg}$ percent GAE (Table 7). These data are within the range reported in the literature for prickly pear juice aof round $65 \mathrm{mg}$ of polyphenols per $100 \mathrm{~mL}$ of juice (Nazareno and González, 2008). This information is important for the antioxidant activity of this bioactive component.

Table 7. Total polyphenols, rumpa (Eulychnia acida) fruits, expressed as equivalents of gallic acid (EGA), in pulp with seed fraction in three sectors sampled in summer 2009.

\begin{tabular}{|c|c|c|c|c|}
\hline \multirow{2}{*}{$\frac{\text { Sector }}{\text { Peel color }}$} & \multicolumn{2}{|c|}{ Manquehua } & \multirow{2}{*}{$\frac{\text { Gualliguaica }}{\text { Green }}$} & \multirow{2}{*}{$\begin{array}{c}\text { Quebrada } \\
\text { Honda }\end{array}$} \\
\hline & Green & Pink & & \\
\hline & \multicolumn{4}{|c|}{ 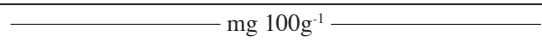 } \\
\hline $\begin{array}{l}\text { Total polyphenols } \\
\text { mg \% EGA }\end{array}$ & $54.3 \pm 6.4 \mathrm{a}$ & $55.6 \pm 10.7 \mathrm{a}$ & $65.6 \pm 1.4 \mathrm{a}$ & $71.0 \pm 9.4 \mathrm{a}$ \\
\hline Range mg \% EGA & $49.4-61.6$ & $44.3-65.6$ & $65.1-67.2$ & $60.4-78.1$ \\
\hline
\end{tabular}

Mean value \pm standard deviation; $N=3$. Mean values in the same letters indicate no significant differences at $\mathrm{P}<0.05$. 
Other interesting bioactive components were the pigments, principally betalains in cacti. These pigments are classified as betacyanin (expressed as betanin equivalents) and betaxanthin (expressed as indicaxantin equivalents). In 2009, a preliminary determination was done of rumpa pink peel samples from the Manquehua sector. In 2010, a second analysis of these pigments was done on pink peels obtained from rumpa collected in the central valley areas of Gualliguaica and Manquehua (Table 8). Total betalain pigment content of fruit from Manquehua in 2010 was lower than the values obtained in the three sub-sectors sampled in 2009, but higher than the ones obtained from Gualliguaica. The content of both pigments was lower than what is reported in the literature for red prickly pears, which has $28 \mathrm{mg} 100 \mathrm{~g}^{-1}$ of betacyanin equivalents and $10 \mathrm{mg} 100 \mathrm{~g}^{-1}$ of betaxantin equivalents in red pulp (Sepúlveda and Sáenz, 1990). This difference in red pigment content compared to that of the red Opuntia sp. is because the Mexican nopal has quite strong red pulp and peel, while rumpa peel is light pink, closer to pink prickly pear fruit, which has a total betalain content of approximately 1.1-4.1 mg 100 $\mathrm{g}^{-1}$ (Sáenz, 2006). The differences in betalain pigment content in pink-peeled rumpa sampled from different sectors and two summer seasons suggests that further research is necessary in this area to quantify the variations in different years of harvesting in the same sectors and thus clarify their natural behavior.

Table 8. Total betalains, betacyanin (expressed as equivalents of betanine) and betaxanthin (expressed as equivalents of indicaxantins) content in pink peel in fresh weight of rumpa (Eulychnia acida) fruits, sampled in summer 2009 and 2010.

\begin{tabular}{|c|c|c|c|c|c|}
\hline Year & Sector & $\begin{array}{l}\text { Sub } \\
\text { Sector }\end{array}$ & $\begin{array}{c}\text { Betacyanin } \\
\text { equiv., } \\
\text { betanine }\end{array}$ & $\begin{array}{l}\text { Betaxanthin } \\
\text { equiv., } \\
\text { indicaxantin }\end{array}$ & $\begin{array}{c}\text { Total } \\
\text { betalains }\end{array}$ \\
\hline & & & 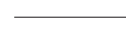 & $\operatorname{mg~} 100 \mathrm{~g}^{-1}$ & \\
\hline \multirow[t]{3}{*}{2009} & Manquehua & El Espinal & 1.2 & 0.6 & 1.80 \\
\hline & (Limari Valley) & El Infiernillo & 1.4 & 0.6 & 2.00 \\
\hline & & Los Cardos & 2.5 & 1.7 & 4.20 \\
\hline \multirow[t]{2}{*}{2010} & $\begin{array}{l}\text { Gualliguaica } \\
\text { (Elqui Valley) }\end{array}$ & & $0.40 \pm 0.1$ & $0.40 \pm 0.1$ & 0.80 \\
\hline & $\begin{array}{l}\text { Manquehua } \\
\text { (Limari Valley) }\end{array}$ & & $0.75 \pm 0.0$ & $0.86 \pm 0.1$ & 1.61 \\
\hline
\end{tabular}

\section{CONCLUSIONS}

This research generated the chemical and nutritional information about $E$. acid Phil. fruit, in its three fractions: pulp with seeds, peel, and juice.

Regarding weight, fruits from Manquehua were smaller than those from the other two sectors in the two evaluated seasons, but they presented a better yield between pulps with seeds related to peel. The peel represented more than $50 \%$ of the whole fruit in all the sampled rumpas. Regarding the nutritional chemical composition of the three fractions, dietary fiber was the main component, which presented a jellied and filamentous texture characteristic of these fruits. Regarding micronutrients, there was a notably higher content of vitamin $\mathrm{C}$ in the three studied fractions compared to other common fruits. The presence of mainly $\mathrm{K}$ and $\mathrm{Mg}$ and its high water content makes rumpa a promising raw material for agroindustrial development of products such as natural juices or isotonic drinks. The preliminary information about total polyphenol and betalain pigment content in fruit fractions indicates low values compared to other fruits. It is necessary to study which aspects of climate and soil may affect the chemical composition of rumpa for a better evaluation of the potential development of innovative products from rumpa fruit and its fractions.

\section{ACKNOWLEDGEMENTS}

The authors thank Innova Chile of CORFO for supporting this research through the project "Copao (Eulychnia acida Phil.), cactus endemic to Chile: Nutraceutical properties determination and potential of agro-industrial use", Code11 7CT91GM. The authors are also grateful to Lucía Martínez G. for assistance in fieldwork and David López Aspe of CEAZA who prepared the regional map.

Características químicas y composición nutricional de los frutos de copao (Eulychnia acida Phil.) bajo tres condiciones ambientales de la Región de Coquimbo. El copao (Eulychnia acida Phil.) es un cactus arborescente endémico restringido principalmente a la región semi árida de Coquimbo (2954’28" S, 71²15'15" O), Chile. $\mathrm{El}$ área de distribución comprende desde el nivel del mar hasta los 1200 m de altitud. Los frutos llamados "rumpa", son redondos, piel de color verde o rosado con pequeñas escamas, y amplia variabilidad en peso y tamaño. El objetivo del trabajo fue caracterizar el fruto en tres sectores de la Región de Coquimbo de acuerdo a parámetros químico-nutricionales y componentes bioactivos en diversas fracciones del fruto: pulpa con semilla, jugo y piel, con el fin de visualizar posibles aplicaciones en la industria. Esta investigación mostró que la "rumpa" es una buena fuente natural principalmente de fibra dietética soluble, de consistencia gelatinosa, presente en las tres fracciones analizadas con valores de $2 \%$ para jugo, $3 \%$ pulpa con semilla y alrededor de $5 \%$ para piel, constituyéndose en una buena fuente potencial de hidro coloides para la industria de alimentos. Además es una buena fuente de vitamina $\mathrm{C}$ alrededor de $55 \mathrm{mg} 100 \mathrm{~g}^{-1}$ en la piel y $30 \mathrm{mg} 100 \mathrm{~g}^{-1}$ en pulpa con semillas y jugo, valores altos comparados con el contenido en tunas (Opuntia ficus-indica [L.] Mill.) Los principales minerales fueron $\mathrm{Mg}, \mathrm{Ca}, \mathrm{P}, \mathrm{y} \mathrm{K}$. En la pulpa con semillas se determinaron polifenoles totales y en la cáscara rosada se determinaron los pigmentos betalaínas. Las características nutricionales, junto al alto contenido de agua, alrededor de $96 \%$, hacen de la "rumpa" una materia prima promisoria para el desarrollo de jugos o bebidas isotónicas naturales. Esta caracterización contribuye a una valorización productiva de una especie nativa endémica disminuyendo las potenciales amenazas de destrucción 
de las poblaciones silvestres de E. acida, especialmente aquellas cercanas a sectores agrícolas, favoreciendo la conservación de su hábitat en la región.

Palabras clave: Rumpa, cactus arborescente, minerales, vitamina $\mathrm{C}$.

\section{LITERATURE CITED}

Askar, A., and S. El-Samahy. 1981. Chemical composition of prickly pear fruits. Deutsche Lebensmittel-Rundshau 77:279-281.

AOAC. 1990. Official methods of analysis of the Association of Official Analytical Chemists. 1298 p.15 $15^{\text {th }}$ ed. Association of Official Analytical Chemists (AOAC), Washington, D.C., USA.

AOAC. 1995. Official methods of analysis of the Association of Official Analytical Chemists. $16^{\text {th }}$ ed. Arlington, Virginia, USA.

Belitz, H., and W. Grosch. 1999. Food chemistry. Springer-Verlag, Berlin, Germany.

Bligh, E., and W. Dyer. 1959. A rapid method of total lipid extraction and purification. Canadian Journal of Biochemistry and Physiology 37:911-917.

Bustamante, M. 1996. Distribución, estado de conservación y uso de las cactáceas columnares en la región de Coquimbo. 101 p. Memoria de título Ingeniero Agrónomo. Universidad de Chile, Santiago, Chile.

Cappelli, P., and V. Vannucchi. 1990. Chimica degli alimentiConservazionine e transfornazioni; Zanichelli, Bologna, Italy.

Casas, A.C., J.A. Valiente-Baunet, J.A. Soriano, and P. Dávila. 1999. Morphological variation and the process of domestication of Stenocereus stellatus (cactacea) in Central Mexico. American Journal of Botany 86:522-533.

CEAZA. 2010. Red agroclimática. Red Meteorológica, Centro de Estudios Avanzados en Zonas Áridas (CEAZA), La Serena, Chile. Available at http://www.ceazamet.cl (accessed July 2010).

Domínguez-López, A. 1995. Review: Use of the fruits and stems of prickly pear cactus (Opuntia spp.) into human food. Food Science and Technology International 1:65-74.

Fleet, J., and K. Cashman. 2003. Cap. 28. Magnesio. 873 p. In Bowman, B., and R. Russell (eds.) Conocimientos actuales sobre nutrición. Publicación Científica y Técnica № 592. Organización Panamericana de la Salud, Washington D.C., USA.

García-Suárez, F., L. Carreto-Montoya, R. Cárdenas-Navarro, J.C. Díaz Pérez, and R. López Gomez. 2007. Pitaya (Stenocereus stellatus) fruit growth is associated to wet season in Mexican dry tropic. Фyton. International Journal of Experimental Botany 76:19-26.

Gugliuzza, G., P. Inglese, and V. Farina. 2002. Relationship between fruit thinning and irrigation on determining fruit quality of cactus pear (Opuntia ficus-indica) fruits. Acta Horticulturae 581:205210.

Gurrieri, S., L. Miceli, M. Lanza, F. Tomaselli, R. Bonomo, and E. Rizarelli. 2000. Chemical characterization of Sicilian prickly pear (Opuntia ficus indica) and perspectives for the storage of its juice. Journal of Agricultural and Food Chemistry 48:5424-5431.

Guzmán-Maldonado, S., G. Herrera-Hernández, D. HernándezLópez, R. Reynoso-Camacho, A. Guzmán-Tovar, F. Vaillant, and P. Brat. 2010. Physicochemical, nutritional and functional characteristics of two underutilized fruit cactus species (Myrtillocactus) produced in central Mexico. Food Chemistry 121:381-386

Inglese, P., G. Barbera, and T. La Mantia. 1999. Seasonal reproductive and vegetative growth pattern and resource allocation during Cactus Pear [Opuntia ficus-indica (L.) Mill.] fruit growth. HortScience 34:69-72.

Lester, G.E. 2006. Environmental regulation of human health nutrients (ascorbic acid, B-carotene, and olic acid) in fruits and vegetables. HortScience 41:59-64.

Lester, G.E., and K.M. Crosby. 2002. Ascorbic acid, folic acid, and potassium content in postharvest green-flesh honeydew muskmelon fruit: Influence of cultivar, fruit size, soil type and year. Journal of the American Society for Horticultural Science 127:843-847.

Luna, M.C. del C. 2006. Clasificación y ordenación morfológica del fruto de variantes cultivadas de pitaya (Stenoceresus pruinosus (OTTO). Buxb) en la Mixteca Baja, México. Revista Chapingo. Serie Horticultura 12:245-251.

Masson, L., C. Camilo, K. González, A. Cáceres, N. Jorge, and E. Torija. 2008. New sources of oilseeds from Latin American native fruits. Natural Product Communications 3:357-362.

Ministerio de Salud. 2005. Resolución 1255 Exenta, 13.01.2005 Gobierno de Chile, Ministerio de Salud (MINSAL), Santiago, Chile.

Mulas, M., and G. D’hallewin. 1997. Fruit quality of four cactus pear (Opuntia ficus-indica Mill.) cultivars as influenced by irrigation. Acta Horticulturae 438:115-122.

Multon, J. 2000. Aditivos y auxiliares de fabricación en las industrias agroalimentarias. 806 p. Ed. Acribia, Zaragoza, España.

Muñoz de Chávez, M., A. Chávez, V. Valles, and J. Roldan. 1995. The nopal: A plant of main fold quality. World Review of Nutrition and Dietetics 77:109-134.

Nazareno, M., and E. González. 2008. Antioxidants properties of cactus products. Cactusnet 11:18-28.

Nefzaoui, A., M. Nazareno, and M. El Mourid. 2008. Review of medicinal uses of cactus. Cactusnet 11:3-15.

Nyffeler, R., U. Eggli, and B.E. Leuenberger. 1997. Noteworthy idioblastic sclereids in the stems of Eulychnia (Cactaceae). American Journal of Botany 84:1192-1197.

Osborne, D., and P. Voogt. 1986. Analysis of food nutrients. 285 p. Ed. Acribia S.A., Zaragoza, Spain.

Pimienta, E. 1990. El nopal tunero. University of Guadalajara, Guadalajara, México.

Preuss, H. 2003. Sodium, chloride and potassium. In Bowman, B., and R. Russell (eds.) Present knowledge in nutrition. Chapter 29. Scientific and Technical Publication No 592.873 p. Pan American Health Organization, Washington D.C., USA.

Rodríguez, S., C. Orphee, S. Macías, S. Generoso, and L. Gómez García. 1996. Prickly pear: physicochemical properties of two varieties: Alimentación Latinoamericana 210:34-37.

Sáenz, C. 2006. Utilización agroindustrial del nopal [Agroindustrial use of nopal]. FAO Agricultural Services Bulletin $N^{\circ}$ 162. FAO, Rome, Italy.

Sawaya, W., H. Khatchadourian, W. Safi, and H. Al-Hammad. 1983. Chemical characterization of prickly pear pulp, Opuntia ficus indica, and the manufacturing of prickly pear jam. Journal of Food Technology 18:183-193.

Schmidt-Hebbel, H., M.I. Pennacchiotti, L. Masson, y M.A. Mella. 1992. Tabla de composición química de alimentos chilenos. $8^{\mathrm{a}}$ ed. Universidad de Chile, Santiago, Chile.

Schmidt-Hebbel, H., M.I. Penacchiotti, L. Masson S., L.J. Vinagre, M.A. Mella, y A.K Alamo. 1977. Métodos de valoración de vitaminas en alimentos. $2^{\text {a }}$ ed. Departamento de Ciencia de los Alimentos y Tecnología de Alimentos. Universidad de Chile, Facultad de Ciencias Químicas, Santiago, Chile.

Sepúlveda, E., and C. Sáenz. 1990. Chemical and physical characteristics of prickly pear (Opuntia ficus-indica) pulp. Revista de Agroquímica y Tecnología Alimentaria 30:551-555.

Singleton, V.L., and J.A. Rossi. 1965. Colorimetry of total phenolics with phosphomolybdic-phosphotungstic acid reagents. American Journal Enology and Viticulture 16:144-158.

Stintzing, F.C., K. Herbach, M. Mosshammer, R. Carle, W. Yi., S. Sellappan, et al. 2005. Color, betalain pattern, and antioxidant properties of cactus pear (Opuntia spp.) clones. Journal of Agricultural and Food Chemistry 53:442-451.

Szakiel, A., C. Pączkowski, and M. Henry. 2010. Influence of environmental biotic factors on the content of saponins in plants. Phytochemistry Reviews. doi:10.1007/s11101-010-9164-2.

Weaver, C. 2003. Calcio. 873 p. In Bowman, B., and R. Russell (eds.) Present knowledge in nutrition. Chapter 26. Scientific and Technical Publication N ${ }^{\circ}$ 592. Pan American Health Organization, Washington D.C., USA. 